\title{
Maat vs. The statue of Égalité: A critical analysis of Ataa Ayi Kwei Armah's Wat Nt Shemsw: The way of companions
}

\section{Qbádélé Kambon}

Senior Research Fellow

Institute of African Studies

University of Ghana

Legon

Email: obkambon@staff.ug.edu.gh

Lwanga Songsore

Research Assistant

Institute of African Studies

University of Ghana

Legon

Email: sungsongsore@gmail.com.

Yaw Mankatah Asare

Research Assistant

Institute of African Studies

University of Ghana

Legon

Email: yaw.mankatah@gmail.com

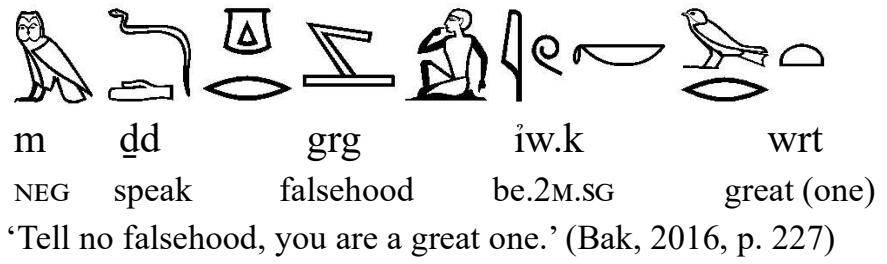

Submitted: February 4, 2020/Accepted: December 18, 2020/ Published: January 28, 2021 


\begin{abstract}
In this paper, we endeavor to restore 3 place by challenging erroneous and demonstrably incorrect notions as they appear in Ataa ${ }^{1}$ Ayi Kwei Armah's Way of Companions. By cross-referencing Ataa Armah's vague allusions to "ancient Egyptian" mythology with actual textual documentation from $\triangle K m t$ 'Black Nation/Land of Blacks' (so-called "ancient Egypt"), we will interrogate the assertions made about the myths of the $\square \frac{9}{11} \mathrm{kmt}(y \mathrm{w})$ 'Black people'. We find that where Ataa Armah's statements are at odds with the texts of $\square m t$ 'Black Nation/Land of Blacks,' it is necessary to bring this information to light so that the readers can learn the actual content of these myths for themselves. In conclusion, we find that to truly understand Kmt 'Black Nation/Land of Blacks,' Afrikan champions interested in restoring the truth of 3 ' $M^{\prime} t$ 'Maat' must let the Ancestors speak without Eurasian interpreters or interpretations.
\end{abstract}

Keywords: Maat, Ayi Kwei Armah, Wat nt Shemsw, egalitarianism

\title{
Background and introduction: Approaching the house of cards
}

Ataa Ayi Kwei Armah has pursued a significant intellectual and cultural project throughout his career earning a place as one of the great writers of the Afrikan world. Further, he has played an important role in the literary life of conscious Afrikans through his works of fiction. Through his writings over the years, he has presented classical Kmt 'Black Nation/Land of Blacks' in the context of fiction used for the reconstruction of consciousness. Notable among such works are Osiris Rising: A Novel of Africa Past, Present and Future and KMT: In the house of life: An epistemic novel (Armah 1995; 2002). His creative writing has imagined our collective future based on our common past. It is important to note, however, that Ataa Armah is a career novelist and novelists are creative

1 Ataa 'father' in Ga, the language from which Ataa Ayi Kwei Armah's name comes and used here as a term of respect in light of Ataa Armah's past contributions throughout the course of his career.

Legon Journal of the Humanities 31.2 (2020)

Page $\mid 34$ 
writers not historians or recorders with a mandate to accurately represent past phenomena. While Ataa Armah has made a career of writing novels ol Wat Nhemsw The Way of Companions, however, is not presented as a novel. It is presented as a work of non-fiction ostensibly based on what the myths of classical $\triangle m t$ 'Black Nation/Land of Blacks' actually say. It is for this reason that Whe Way of Companions constitutes an absolute perversion of truth with regard to the Ancestral myths, culture, and the history of classical $K m t$ 'Black Nation/Land of Blacks.' The book does not even present the actual contents of the myths, it only obliquely refers to them as, indeed, the content of these myths is at odds with the author's ideas about classical $\mathrm{K} m t^{\text {'B Black }}$ Nation/Land of Blacks'. Thus, rather than presenting factual information based on primary sources as would be expected for a work of nonfiction, Ataa Armah appropriates names and terms from Kmt 'Black Nation/Land of Blacks' devoid of the actual context in which their meaning can be found. Whereas in a work of fiction this would present little problem, in a work presented as nonfiction it amounts to a perversion of the truth. Primarily, this perversion of truth is found in the inherent contradiction of using ปه通 Isir 'Isir/Osiris', a divine ruler, to argue against divine rulership; secondly it is due to the obfuscation, de-contextualization, and dissimulation with regard to mythic texts of classical Kmt 'Black Nation/ Land of Blacks.'

Against this backdrop, this review will critique the misrepresentations advanced by Ataa Ayi Kwei Armah in of will be done through a patient presentation of relevant texts from classical $\quad K m t$ 'Black Nation/Land of Blacks.' We find it necessary to set the record straight because Ataa Armah's book, among other things, constitutes the veritable rape of $\Rightarrow \circ M^{\prime} t$ 'Maat' as truth, who is then summarily 
sacrificed on the altar of the eurasian rhetorical ethic ${ }^{2}$ of "egalitarianism"-what we refer to here as the statue of égalité.

The purpose of Ataa Ayi Kwei Armah's Wat Nt Shemsw: The Way of Companions is clearly advanced from the outset: The entire book is devoted to obtaining inspiration from what he refers to as "ancient Egyptian" (more appropriately termed chart a new course for Afrika and Afrikan people on the basis of what Ataa Armah refers to as "egalitarianism." For Ataa Armah, the foregoing mandate is ironically occasioned by his disappointment in Afrikan academics who lie to "African children about African history, philosophy, science, literature, and culture" (Armah, 2018, p. 12). He also decries the untold millennia during which Afrika has been under attack; where Afrikan children learn "a great deal more about European and Arab Ancestors" than they do about their own (Armah, 2018, p. 12). These statements are ironic in that the book itself seems to depend on Afrikan people's ignorance and lack of selfknowledge with regard to the aforementioned areas. This is because those familiar with the actual textual record of $\square$ $K m t$ 'Black Nation/Land of Blacks' will be instantly aware that Ataa Armah's assertions are at variance with the evidence, facts, and truth (D) $M^{3} t$ ) as found in textual and iconographical sources.

The Rhetorical Ethic of "Égalite" Masquerading as
M'ct in Classical $\square \mathrm{Kmt}$ 'Black Nation/Land of Blacks"?

The only primary sources through which the content of the actual myths and the character mythical figures contained therein come from the texts of $\square m t$ 'Black Nation/Land of Blacks' herself. Access to many of these sources, some of which will be presented in this article, is also available

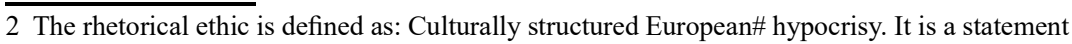
framed in terms of acceptable moral behavior towards others that is meant for rhetorical purposes only. Its purpose is to disarm intended victims of European cultural and political imperialism. It is meant for "export" only. It is not intended to have significance within the culture. Its essence is its deceptive effect in the service of European power. (Ani, 1994: pp. xxv-xxvi) 
in translation. Further, archaeological and iconographical sources may be used to supplement these primary texts. A non-fiction book that purports to convey actual information about the content of these myths while not only failing to cite these sources but whose interpretations are at odds with these sources amounts to conjecture at best, intentional fraud at worst. Imagination and fanciful claims are perfectly acceptable in a novel, but not when they are presented as though they are a truthful representation of the content of the myths of $K m t$ 'Black Nation/Land of Blacks' when in reality, nothing could be further from the truth $\left(\mathrm{C}^{\mathrm{s}} \mathrm{c} t\right)$. In the entirety of Dat Nt Shemsw: The Way of Companions the only two allusions to sources of the content of the myth Ataa Armah interprets consist of two brief mentions of "Seth and Horus" and Plutarch's "paraphrases" (Armah, 2018, pp. 62, 181). ${ }^{3}$

Nonetheless, upon engaging with the actual content of these two texts, it becomes abundantly clear that both of the aforementioned texts alluded to are at odds with Ataa Ayi Kwei Armah's imagined and fictional (mis-)conceptions of so-called

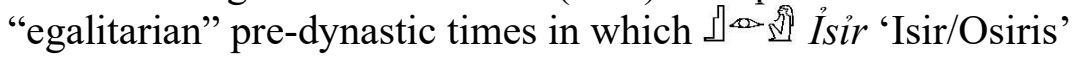
features as his embodiment of the "egalitarian brother."

To begin with, Ataa Armah describes his supposedly egalitarian pre-dynastic period stating that "In the activities of the community, persuasion, not compulsion through the violence of military force, was the norm. It was this process of peaceful, incremental social and economic development, based on egalitarian norms, that the onset of the monarchical age stopped (Armah, 2018, p. 70)." This begs the question of "Is that true?" Further, from what textual and/or iconographical source(s) is he deriving his information? While in a work of fiction-declared as such-these questions would not necessarily be raised, in a work

3 It should be noted here that Plutarch is a secondary if not tertiary source-not even a translation of an original text from Kmt 'Black Nation/Land of Blacks' but rather a Greek man offering syncretistic Greek-influenced re-interpretations thousands of years after these myths were first recorded. Thus, they would be expected to be much less reliable than the texts of the $\operatorname{Kmt}(y w)$ themselves. 
that is not presented as a novel, one's interpretations would be expected to have some basis in historical fact and verifiable reality after consulting with what the myths mentioning Osiris' actually say. In other words, they would be expected to be grounded in the multi-millennial legacy bequeathed to us by

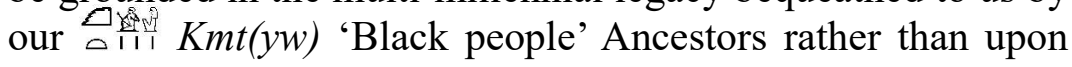
imagination or personal preferences. Ataa Armah further adds that, "the pre-dynastic society of the Nile valley was an agrarian society of equal humans, members of an extended family" (Armah, 2018, p. 181). For Ataa Armah, these members, "the cooperative egalitarians were known as shemsw Maât" (Armah, 2018, p. 93) (italics in original). This leads us to the related questions of "Is this a truthful representation of the actual content of the myth to which he is referring? If so, according to whom?" With just two allusions and without sources, citations or evidence provided, the reader is left to guess. Fortunately, however, various sources of that myth are available for crossreferencing even if Ataa Armah, for whatever reason, has decided not to provide them to his readership.

To continue with Ataa Armah's view from Wat Nt Shemsw: The Way of Companions, we can easily grasp Ataa Armah's conception of his so-called pre-dynastic egalitarian period; an idyllic view which is further juxtaposed with a sinister depiction of the so-called dynastic period, characterized as monarchical, and the dastardly usurper of the latter's former glory. The following extract provides us with evidence to this effect:

In the mythology of pre-dynastic Nile valley society, the cooperative egalitarians were known as the Shemsw Maat. They had a dynamic counterpart, the Shemsw Montw or Shemsw Seth, believers in the greater efficacy of violent, unequal organization as a guarantee of the good life - for a few, at the expense of the many. The way to bring about this 
outcome was for the violent minority to train
itself systematically in the use of ruse and force
in social relations, as against the Shemsw Maat's
recommendation of truth and persuasion. ${ }^{4}$
$[\ldots]$

The egalitarian brother, so says the myth, was first deceived, then assassinated. The values he represented were driven underground. [...] In ancient Egypt, after the destruction of the egalitarian predynastic social system and the suppression of its cultural values, social stratification, bureaucratic government, and theocratic legitimization supported and reinforced each other, creating a system of spectacular ease and splendor at the apex. (Armah, 2018, p. 43) [Bold emphasis added]

In light of the above (mis-)conception about ! Isir 'Isir/Osiris', the so-called "egalitarian brother," we will address the divergences between Ataa Armah's egalitarian, heterarchical, and exoteric portrayal of him and the so-called

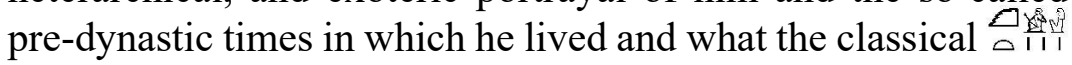
$\operatorname{Kmt}(y w)$ 'Black people' said.

Knocking Down the House of Cards: What the Written

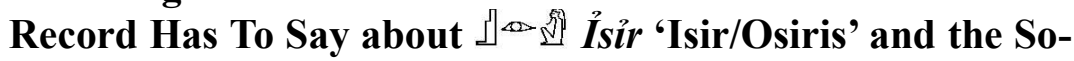

\section{Called Pre-Dynastic Egalitarian Period}

There are several misrepresentations and/or omissions of facts in which amount to a series of intricate and extensive distortions

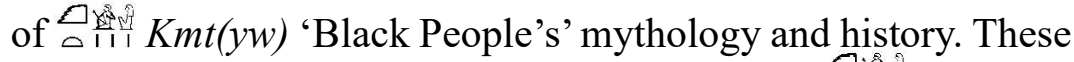
distortions amount to throwing our classical 'Black people' Ancestors under the bus. This is disappointing to

4 This brings up the question of whether force can be used in the restoration of M3't cf. Prophecy of Nfrty for an indigenous view from Kmt 'Black Nation/Land of Blacks' on this question. 
say the least in that, while critiques are necessary, they should at least be grounded within an accurate presentation of evidence and in truth ( it is not conducive for readers to attempt to read Wat Nt Shemsw: The Way of Companions as anything other than fiction presented as nonfiction. In this article, as we provide evidence to dismantle Ataa Armah's unfactual and counterfactual claims, other inaccuracies, misrepresentations, and/or errors found in the book will be discussed and dismantled as the veritable house of cards comes crashing down.

By way of background, in another book of his, Ataa Armah and his 'followers'5 made their initial moves towards conflating $M^{\prime} t$ 'Maat' with the eurasian rhetorical ethic of egalitarianism stating the following:

[...] the group of Osiris, devoted to cooperation, did not aim at dominance, and thus never entered the struggle as a belligerent - the narrative of the suppression of egalitarian norms, Maat, got centered around the generation of Horus, not Osiris. The world has lived with the victory of the militarists in matters of social governance since then" (Bak, 2016, p. xiv). (bold emphasis added)

Similarly, in Companions, Ataa Armah presents so-called pre-dynastic Kmt 'The Black Nation/Land of Blacks' as egalitarian, nonviolent, peaceful, anti-hierarchy, anti-kingship/rulership. This is Ataa Armah's utopian so-called pre-dynastic period in which ป period which, according to him, was the exact opposite of the socalled dynastic period. The textual evidence below in translation, which comes from the "Great Hymn to Osiris", however, 5 An explanation of this term will be given below. 6 Osiris is the Greek version of Îsir, which is the original. 
suggests that Ataa Armah's portrayal might not be accurate: ${ }^{7}$

Hail to you, Osiris,

Lord of eternity, king of gods,

Of many names, of holy forms,

Of secret rites in temples!

Noble of ka he presides in Djedu,

[...]

Eternal lord who presides in Abydos

[...]

The joined Two Lands adore him,

When His Majesty approaches,

Mightiest noble among nobles,

Firm of rank, of lasting rule.

Good leader of the Nine Gods,

[...]

Geb's heir (in) the kingship of the Two Lands,

Seeing his worth he gave (it) to him,

To lead the lands to good fortune.

[...]

And the Two Lands are content with it.

Appearing on father's throne, (Lichtheim, 1976,

p. 81-3) [Emphasis added]

In other words, the "egalitarian brother" has a throne and all the other paraphernalia of kingship, which he then passed

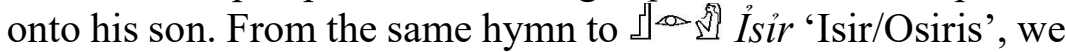
find the following:

7 While a translation is provided here, it is important to stress that the original publication, including the original mdw nTr text should always be consulted for avoidance of doubt. The original publication is Moret, Alexandre (1930) La légende d'Osiris à l'époque thébaine d'après l'hymne à Osiris du Louvre, dans : Bulletin de l'Institut Français d'Archéologie Orientale 30, Le Caire 1930, pp. 725-750. While the translation used here is not the best, it at least gives the reader a sense of what Ataa Armah is not telling us about what the only textual sources on the myth which he purports to accurately portray actually say. 
The eldest of the Nine Gods,

Who set Maat throughout the Two Shores,

Placed the son on his father's seat.

Lauded by his father Geb,

Beloved of his mother Nut

Mighty when he fells the rebel,

Strong-armed when he slays his foe.

Who casts fear of him on his enemy,

Who vanquishes the evil-plotters,

Whose heart is firm when he crushes the rebels.

(Lichtheim, 1976, pp. 82-3)

And this is who Ataa Armah says was non-violent and

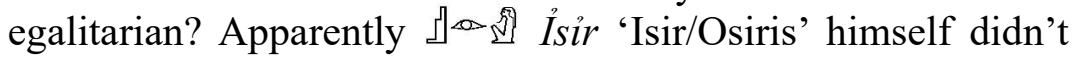
get the memo! This begs the question of, if Ataa Armah is not

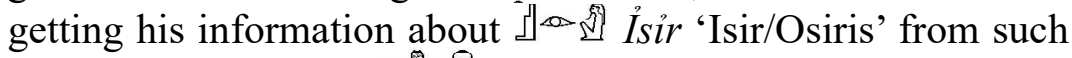
actual sources from $\quad K m t$ 'The Black Nation/Land of Blacks', other than his own creative imagination, where exactly is Ataa Armah drawing his information from? In other words, without evidence, the uninformed reader is forced to just take his word for it. Meanwhile the informed reader will be instantly aware that Ataa Armah's claims about ปه are not supported by the texts of $\square$ Kmt 'The Black Nation/ Land of Blacks'.

In another text by Ataa Ayi Kwei Armah and his $\check{s} m s w$ ' followers', a passage states that "Maat is fundamentally about truth, and truth is fundamentally incompatible with royal power." (Bak, 2016, p. X). So this brings us to the question of why, then, did Ataa Ayi Kwei Armah choose له通 Isir 'Isir/ Osiris', the very embodiment of royal power and whose son, $\mathrm{Hr}$ 'Heru/Horus,' every ruler of $\mathrm{Kmt}$ 'The Black Nation/ Land of Blacks' embodied as the reincarnation of? Indeed, Ataa Ayi Kwei Armah is apparently unaware that in his utopian socalled "pre-dynastic" times, there were so-called "pre-dynastic" rulers known as the 
政 $\mathrm{Hr}$ 'Heru/Horus' was viewed as having inherited the divine throne from his father لـ Isir 'Isir/Osiris.' Indeed, even the beginner interested in so-called "Ancient Egypt" knows that

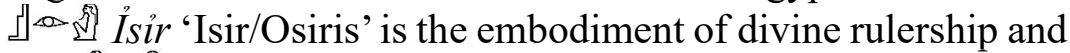

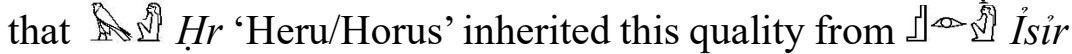
'Isir/Osiris'

It is easy to see from the excerpts above that the peaceful

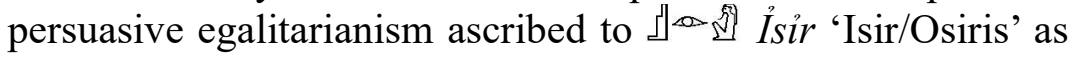
the protagonist of so-called pre-dynastic era by Ataa Armah is not derived from the texts of the

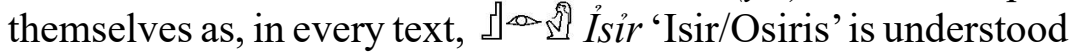
to be a divine ruler and is depicted as such. This was a position which existed even before the invention of writing during the socalled pre-dynastic epoch as attested by copious iconographic and archaeological evidence as will be presented in part two (2) of this article.

Yet, beyond the omission of such sources in service of the eurasian rhetorical ethic of 'egalitarianism', there is also an instance where Ataa Armah decontextualizes the only source he quotes from the entirety of $\square m t$ 'The Black Nation's/ Land of Blacks' history in the book. Again, it is noteworthy that the six words taken out of their original context are the only direct quote that Ataa Armah features from the mass of primary sources from classical $\square K m t$ 'Black Nation/Land of Blacks' whereby he says:

An individual might not really believe that the king was God on earth, but if he spoke about the king in public, it was in his interests to articulate the royal lie. Maat, the culture of truth, as one ancient text about the confrontation of Seth and Horus complains, was 'made to sink into the underworld.' That is to say, truth was driven firmly underground, and the public space was given over to staged emotions, lying utterances, and the bombast of aristocratic gesture 
and speech (Armah, 2018, p. 181). [emphasis added]

In actual fact, the text from which the original quote was taken has absolutely nothing to do with staged emotions, lying utterances or the bombast of aristocratic gesture and speech or articulating any royal lie. In fact, according to the myth, that we would err on the side of thinking Ataa Armah actually read, after the death of nswt bity ป⿻上丨⿶凵 Isir 'Isir/Osiris', the whole contestation between $\mathrm{Hr}$ 'Heru/Horus' and $s t h$ 'Seth' was based on who will be the next

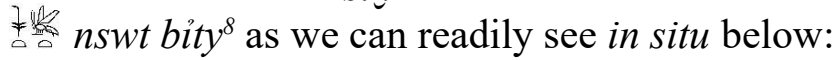

[...] Thoth sat down to compose a letter to Osiris as follows: [...] "Write us what we should do about Horus and Seth, so that we do not take action in ignorance!"

He [Osiris] cried out aloud when the letter was read before him. He replied in great haste to where the All-Lord was with the Ennead, saying: "Why is my son Horus being defrauded when it was I who made you strong?" [...]

The letter of the All-Lord reached Osiris and was read before him. Then he wrote to Pre-Harakhti again, saying: "Very good is all you have done and what the Ennead has found to do! Maat has been made to sink into the netherworld! Now you pay attention to this matter! The land in which I am is full of savagelooking messengers who fear no god or goddess. If I send them out, they will bring me the heart of every evildoer, and they will be here with me! [...] Who among you is mightier than I? [...] When Ptah the Great, South-of-his-Wall, Lord of Memphis, created the sky, did he not say to the stars in it: 'You shall go to rest in the west every night, in the place where

8 Conventionally translated as "Dual King" (i.e. King of Upper and Lower Kmt). The conceptual baggage that comes with the eurasian terminology of "King," however, makes it desirable to leave the actual term and concept of nswt bity untranslated. 
King Osiris is? [...] Seth said to him: "[...] Let Horus, son of Isis, be summoned, and let him be given the office of his father Osiris!" (Lichtheim, 2006, p. 221-2) [Emphasis added]

Why did Ataa Armah not give us the actual context so that we would know that له I Isir 'Isir/Osiris' is saying that $\Rightarrow$ - Ms' $t$ 'Maat' has been made to sink into the netherworld because his son, the right and legitimate royal heir to $n s w t$

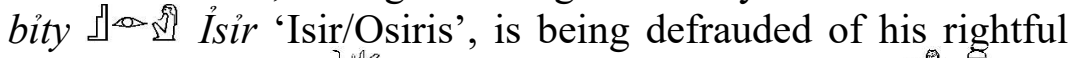
position as the new 'The Black Nation/Land of Blacks'? Therefore, according to the myth itself, له Is Isir 'Isir/Osiris', Ataa Armah's so-called "egalitarian brother" coerces the other 977 ntrw 'divinities' with the threat of violence. Recall that according to Ataa Armah, ป $\infty$ 요 Isir 'Isir/Osiris', in the activities of his community used "persuasion, not compulsion through the violence of military force" (Armah, 2018, p. 70). However, once again the texts of $\triangle K m t$ 'Black Nation/Land of Blacks' seem to be at odds with the claims of Ataa Armah. Thus, we are left with the dilemma of whether to believe Ataa Armah or to believe our

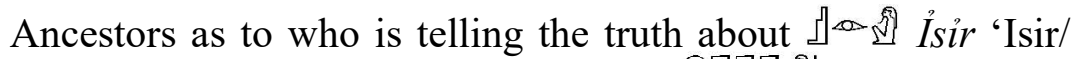
Osiris'. Also, based on the myth, the $\ominus 777$. was slow to place $\mathrm{Hr}$ 'Heru/Horus' on the throne that was rightfully his by virtue of being the son of له I Isir 'Isir/ Osiris'. The above quote from the myth augments the evidence already proffered to call into question the claims of the so-called pre-dynastic era as consistent with the eurasian rhetorical ethic of "egalitarianism." We see that far from addressing staged emotions, lying utterances or the bombast of aristocratic gesture and speech or articulating any royal lie as Ataa Armah would have us believe, the so-called "egalitarian brother", لปه 요 Isir 'Isir/Osiris', is actually agitating on behalf of his son, $\mathrm{Hr}$ 'Heru/Horus', or else his "savage-looking messengers" will bring him the hearts of those deemed to be evildoers. Coercion 
with the threat of violence is not the same as "persuasion" in any case. It appears that Ataa Ayi Kwei Armah has chosen, for whatever reason, to intentionally take the quote out of context to make it match his interpretation rather than letting us know what the actually said.

With this background, the story "Horus and Seth" will undoubtedly make a lot more sense as the entire plot of the story centers on which of the two will be the next ruler-a position formerly held by ป

Let us also consider the following quote from Ataa Armah and his 13 斯 $s m s w$ 'followers' in reference to so-called dynastic times and see if it can be as easily applied to the socalled pre-dynastic "egalitarian brother":

The system of inequality depends on belief in one of the oldest social inventions of African society, divine kingship. God is, after all, the very model of an allpowerful, centralizing dictator, a monarch. The king is endowed with extraordinary powers because God gifts them to him. God chooses to endow a single person with so much power and virtue because he is a God of imbalance, and partial to his beloved son. (Bak, 2016, p. viii)

The textual documentation about لـ is unanimous that indeed he is partial to his beloved son $\mathrm{Hr}$ 'Heru/Horus', and ป to make sure that his son ascends to the throne as we saw in the preceding text. Thus, the informed reader must be truly flabbergasted at Ataa Armah's book, which is not presented as fiction yet, is at odds with actual textual sources from $K m t$ 'Black Nation/Land of Blacks'. Indeed, if Ataa Armah did not learn about ل迹 Isir 'Isir/Osiris' from the written legacy bequeathed to us by our Ancestors, from whence has he derived 
his information that he is presenting to his readers as though it is factual?

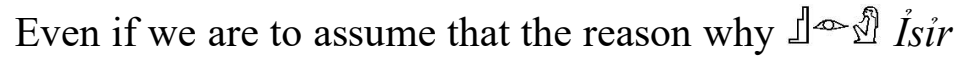
'Isir/Osiris' is presented as peaceful and the times in which he lived as egalitarian is because Ataa Armah is unfamiliar with the primary sources or even their translations, as have been quoted above, his own profession of familiarity with Plutarch suggests

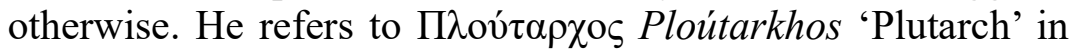
his own words saying "The narrative of Osiris, thanks in part to the paraphrases of Plutarch, is relatively well known" (Armah, 2018 , p. 28). This is the second of only two texts referred to by Ataa Armah in Companions as a source of information from the entirety of the history of Kmt 'Black Nation/Land of Blacks'. Thus, it is difficult to fathom how, from that very same text, he missed the violent and vengeful actions of the so-called "egalitarian

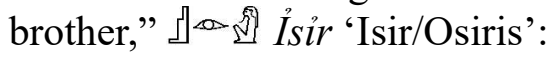

Later, as they relate, Osiris came to Horus from the other world and exercised and trained him for the battle. After a time Osiris asked Horus what he held to be the most noble of all things. When Horus replied, "To avenge one's father and mother for evil done to them," Osiris then asked him what animal he considered the most useful for them who go forth to battle; and when Horus said, "A horse," Osiris was surprised and raised the question why it was that he had not rather said a lion than a horse. Horus answered that a lion was a useful thing for a man in need of assistance, but that a horse served best for cutting off the flight of an enemy and annihilating him. When Osiris heard this he was much pleased, since he felt that Horus had now an adequate preparation. 
(Plutarch, 1936, p. 47)

It should be noted that training for battle, cutting off the flight of an enemy and annihilating him are hardly the picture of peaceful "persuasion." "Osiris" was perhaps unaware that he would be repurposed as Ataa Armah's Enlightenment" age pacifist "egalitarian brother." Indeed, here in the source to which

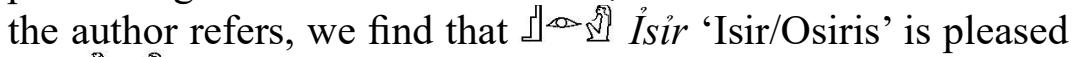
that $H r$ 'Heru/Horus' has adequate preparation to most nobly avenge his father for evil done to him. Thus, for the sake

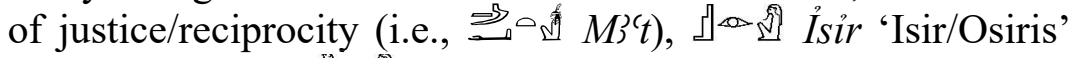
is training his son $\mathrm{Hr}$ 'Heru/Horus' in the use of "force in social relations." In effect, we are missing the supposed "Shemsw Maat's recommendation of truth and persuasion" (Armah, 2018, p. 43), which is characteristic of Ataa Armah's newly-created myth anachronistically assigned to his paradiasical so-called predynastic period. In other words, the actual source of the author's information seems to be at odds with the author's interpretation with regard to the state of affairs of the so-called pre-dynastic

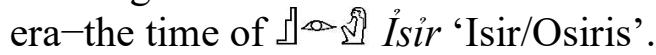

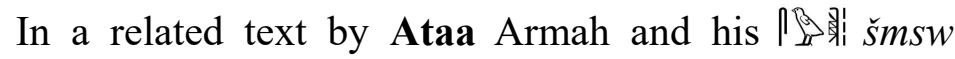
'followers', they state that:

If we analyze the myth of the confrontation between Horus and Seth as a densely summarized historical narrative, it should not be hard to see that at the moment of confrontation, the systematic use of theft in economic, political and social affairs, with the backing of armed force (in effect, armed robbery as a way of life) was a new, unexpected and overwhelmingly potent development. (Bak, 2016, p. xiv)

Why, though, is the actual context and cause of the confrontation (a question of inheritance of divine power to rule) missing from the analysis of Ataa Armah and his 13 取 
'followers'? Why is the actual content of the myths in question being hidden from view such that we are forced to rely on Ataa Armah's dubious interpretations? What happened to "Maat, the culture of truth" (Armah, 2018, p. 181)? This may be puzzling to anyone who is aware that in every extant version of the mythical narrative, $\mathrm{Hr}$ 'Heru/Horus' the son of 50 ? Isir 'Isir/ Osiris' ultimately defeated $s t h$ 'Seth', avenged his father and ascended to his father's throne ${ }^{9}$ with both of his parents' help. This is certainly the case in the only two sources to which Ataa Armah refers, Plutarch and "Horus and Seth." Sources of the myth about so-called pre-dynastic times as the time of $\mathrm{Hr}$ 'Heru's/Horus's' triumph over $\mathrm{N}$ sth 'Seth' and ascension to his father's throne include the "Great Hymn to Osiris":

Seth said to him: "Not so, my good lord. Let Horus, son of Isis, be summoned, and let him be given the office of his father Osiris!" 10

They brought Horus, son of Isis. They placed the White Crown on his head. They placed him on the seat of his father Osiris and said to him: "You are the good King of Egypt! You are the good lord of all lands for ever and ever!" Then Isis uttered a loud shout to her son Horus, saying: "You are the good King! My heart rejoices that you will brighten the earth with your lustre!" [...] "Horus. son of Isis, has risen as Ruler." [...] And Isis said:

"Horus has risen as Ruler, life, prosperity, health! $[\ldots]$

As they see Horus, son of Isis

9 Interestingly, as attested in Vygus (p. 1051) one of the words for throne in Kmt was s' $n$ ht M't 'That which causes $M^{3} t$ to live.' Another was $i s / s t$, which, interestingly, features prominently in the name Isir. It is also worth noting that in both so-called pre-dynastic and dynastic times, the right to rule was based on one's relationship to royal women.

10 For the son to be given the office of his father seems to be the beginnings of a "dynasty" in what Ataa Armah calls "pre-dynastic" times. Again, this is male-to-male succession and inheritance counter to what Ataa Armah says pertained in so-called pre-dynastic times in Wat Nt Shemsw: The Way of Companions. 
Given the office of his father,

Osiris, lord of Busiris." (Lichtheim, 1976, p. 222-

3) [Emphasis added]

"Welcome, Son of Osiris,

Horus, firm-hearted, justified,

Son of Isis, heir of Osiris!"

The Council of Maat assembled for him

The Ennead, the All-Lord himself,

The Lords of Maat, united in her,

Who eschew wrongdoing,

They were seated in the hall of Geb,

To give the office to its lord,

The kingship to its rightful owner.

Horus was found justified,

His father's rank was given him,

He came out crowned by Geb's command.

Received the rule of the two shores.

The crown placed firmly on his head,

[...]

Majesty has taken its seat,

$[\ldots]$

The land has peace under its lord.

Maat is established for her lord,

One turns the back on falsehood.

May you be content, Wennofer!

Isis' son has received the crown,

His father's rank was assigned him (Lichtheim, 1976, p. 84-5) [Emphasis added]

Thus, as we can clearly see, contrary to the view propounded by Ataa Armah, so-called Pre-Dynastic times were seen by indigenes of $\square m t$ 'The Black Nation/Land of Blacks' themselves as the triumph of $\mathrm{Hr}$ 'Heru/Horus' over 两 sth 'Seth'. Indeed, either we must believe that Ataa Armah 
has not read the very texts with which he claims familiarity or there is some degree of intentional disingenuity afoot.

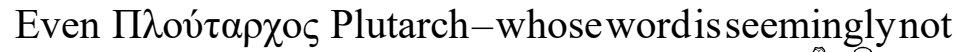
disqualified by Ataa Armah like that of the indigenes of $\square$ Kmt

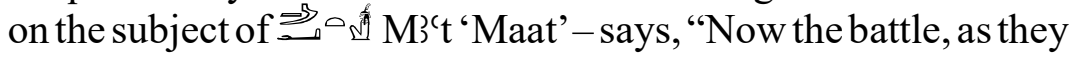
relate, lasted many days and Horus prevailed" (Plutarch, 1936) ${ }^{11}$. However, oddly enough, Ataa Armah manages to ignore any reference to this event as well and pulls from where we know not the conclusion that "The human incarnation of Sethian power 12 at the start of dynastic rule in ancient Egypt was Narmer." It should be noted that the title of this ruler was $\mathrm{Hr} \mathrm{N}^{\mathrm{c}} \mathrm{r}-\mathrm{mr}$ 'Heru Narmer', with the $H r$ 'Heru/Horus' prefix denoting a

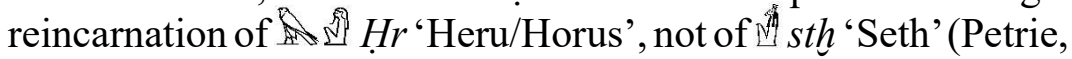
1901, II, plate II (3); Von Beckerath, 1999, pp. 36-37, $\mathrm{x}+4: \mathrm{H1}) .^{13}$ This means that from the very foundation of $K m t$ 'The Black Nation/Land of Blacks', the $n s w t$ bity was understood as the reincarnation of $\mathrm{Hr}$ 'Heru/Horus'. In other words, the indigenous 'Black People' view of the triumph of $H r$ 'Heru/Horus' over $s t h$ 'Seth' is evinced not only in the mythic narrative but also, in the $\mathrm{Hr}$ 'Heru/ Horus' $/ \rho^{\ominus}$ 而 $s r h$ 'Serekh' name of rulers of $\square m t$ 'The Black Nation/Land of Blacks'.

11Apparently, somehow Plutarch avoided being tainted by hierarchy, despite living under the rule of Roman emperors Claudius, Nero, Galba, Otho, Vitellius, Vespasian, Titus, Domitian, Nerva, Trajan and Hadrian (and who is perhaps best known for his Parallel Lives). That's a lot of hierarchy! Thus, it seems that a 'tainted by hierarchy' rationale for disqualifying source texts only applies to $\operatorname{Kmt}(y w)$ 'Black People', whose term, $M_{3}^{3} t$, Ataa Armah kidnaps and misappropriates while dressing égalité up in her clothes.

12 According to the $\operatorname{Kmt}(y w)$ 'Black People', the ruler is the human incarnation of $\mathrm{Hr}$ 'Heru' power.

13 Hrr Nar-mr 'Heru Narmer' Palette (JE32169) 


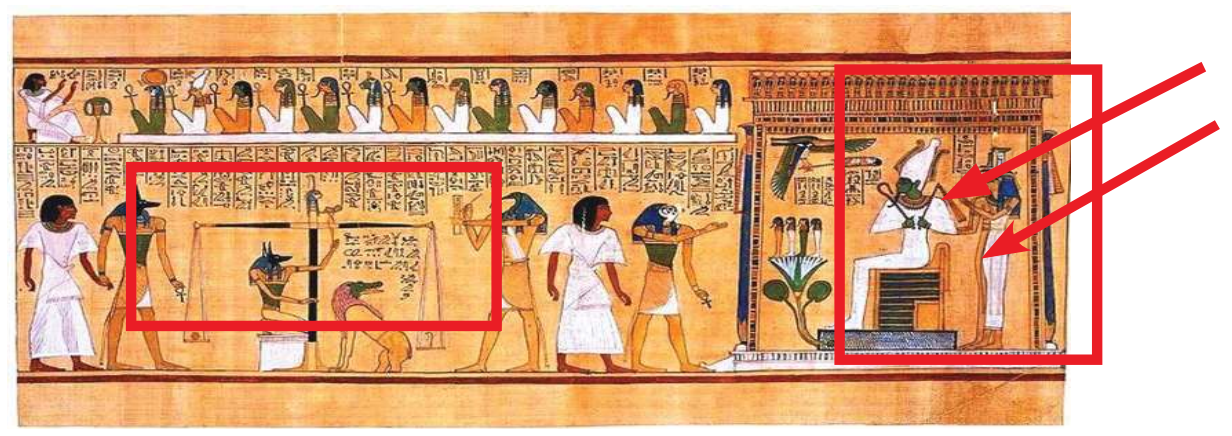

Figure 1: Papyrus of crown, throne and the scales of

At this juncture, we turn our attention to the inherent

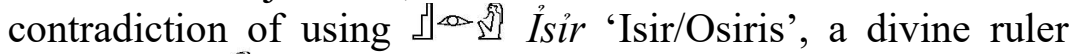
who taught $k m t(y w)$ 'Black people' to "honour the gods", to argue against the divine rulership of so-called dynastic $\square K m t$ 'The Black Nation/Land of Blacks' (presented as being diametrically opposed to pre-dynastic egalitarianism, which 』ळ Isir 'Isir/Osiris' is interpreted by the author as representing) (Plutarch, 1936, p. 35). The texts above and the image displayed in Figure 1 show that the supposed "egalitarian brother" is actually a divine ruler (Armah, 2018, p. 43). Indeed,

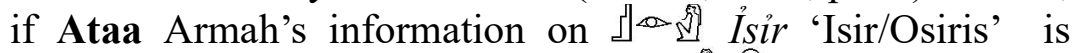
not based on the textual sources of $K m t$ 'The Black Nation/Land of Blacks' nor on its iconography, one can only wonder upon what basis Ataa Armah is making his assertions. Interestingly, the very word لـ Isir 'Isir/Osiris' in Tt $m d w n t r$ 'hieroglyphs' can be represented by a throne and a determinative

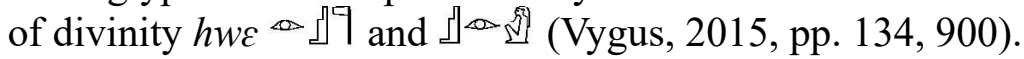

We are cognizant that one could simply say that all of this is just a matter of interpretation. However, we argue that one must present the evidence before we even get to the point of deciding how to interpret it. Whether texts from Kmt 'The Black Nation/Land of Blacks' are to be interpreted literally or figuratively (E.n. mythic ป⿻ 
center of a mythic hierarchy), the least Ataa Armah could do is to quote the texts and give a faithful and accurate accounting of what they say. This is not done in the book because the only way that Ataa Armah's interpretation can go unchallenged seems to be if the reader does not know any of these sources. Indeed, consistent with the rhetorical ethic, the same author who decries lack of knowledge about the past not only perpetuates this lack of knowledge, but actively depends on it for the premise of his book to fly. This is because anyone with even a passing familiarity with the texts of $\square m t$ 'The Black Nation/Land of Blacks' would dismiss Ataa Armah's interpretations, which are not based on these sources, out of hand. The lack of sources from $\square m t$ 'The Black Nation/Land of Blacks' constitutes the sweeping away of footprints and the cleaning up of the crime scene in which $\Rightarrow M^{\prime}$ 't 'Maat' (truth) has been bound and gagged. At any rate, the notion of 50 ? Isir 'Isir/Osiris' as a predynastic anti-hierarchical egalitarian falls apart as soon as these indigenous and even non-indigenous sources are consulted. Here, again, we draw attention to the fact that Ataa Armah is a novelist and a creative writer by trade. While in a novel or overtly declared work of fiction it would not be necessary or even expected for Ataa Armah to present an accurate account of what the Ancestral myths of $\square m t$ 'The Black Nation/Land of Blacks' actually say, in a book that is presented as non-fiction writing, it is egregious to say the least for his readership to be hoodwinked, bamboozled, and led astray in this way.

Indeed, it is abundantly clear that Ataa Armah's interpretation of ป⿻一 Isir 'Isir/Osiris' seems to be at odds with the primary texts of the $\operatorname{Kill}(y w)$ 'Black People' themselves - the ultimate source for any and all information on $\sqrt{2}$ Isir 'Isir/Osiris.' Indeed, preferring to paraphrase a Greek paraphraser, Ataa Armah was able to muster only one single solitary quote from the entirety of the history of $K m t$ 'Black Nation/Land of Blacks' and even that quote of six (6) words out of 3,000+ years' worth of words is taken out 
of context as discussed above. In short, this means that even a novice reader of the book, based on the evidence already given in this article, can easily identify and nullify the modernsensibility-derived eurasian rhetorical ethic of 'egalitarianism'non-violence, "Liberté, égalité, fraternité," "all men are created equal" na kadhalika (n.k.) ${ }^{14}$. - that Ataa Armah falsely ascribes to the so-called pre-dynastic era without presenting a shred of substantive evidence to back up his ulterior misrepresentations.

\section{Summation: Why the House of Cards?}

"African champions must break the chain that links African ideas to European ones and listen to the voice of the ancestors without European interpreters."

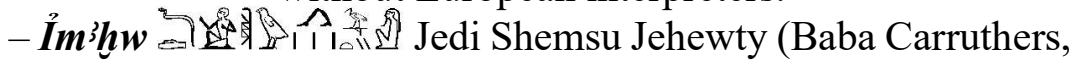
1995, p. xviii)

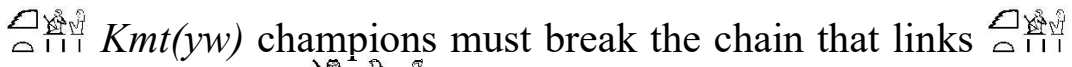
$K m t(y w)$ ideas to the voice of the Ancestors' without interpretations.

Two of the more famous instantiations of the eurasian rhetorical ethic in action — or hypocrisy as a way of life — are in phrases such as "all men are created equal" (written by Thomas Jefferson while enslaving over 600 Afrikans during the course of his life) and "liberte, égalite', fraternite" by the French (while pursuing the re-enslavement of Ayiti) (Ani, 1994: p. 406).

In his own words of reflection about his early (mis-) education $^{15}$ at the hands of eurasians at Achimota School, Ataa Armah inadvertently provides a view of his exposure to the "say one thing, do another" eurasian rhetorical ethic in which hypocrisy is a way of life:

14 n.k. Na kadhalika "And so on" (Kiswahili)

15 We note here that mis-education is not unique to Ataa Armah but is rather endemic to all contemporary Kmtyw (Black people) subjected to the mis-education system decried by Ataa Armah in this very book. (hwe Nana Carter G. Woodson's Miseducation of the Negro) 
Ideas of universal equality and balance were repeatedly invoked as part of the symbolic and emotional atmosphere of Achimota. [...] Rhetorically, the school was all for racial equality. But it was also part of a resolutely racist British empire, so in practice there were tacit compromises. (Armah, 2006, p. 48)

This is Ataa Armah's background, not that of ป⿻ 뇨 Isir 'Isir/Osiris.' As anachronistic and patently absurd as it would be

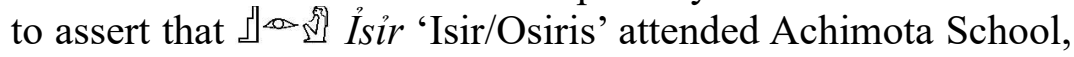
it would be similarly anachronistic to think that he would be a propagator of the eurasian rhetorical ethic of hypocrisy as a way of life in the form of égalité as taught at Achimota.

Once again, we get a clue as to Ataa Armah's motivations from the following quote in an earlier work - The Eloquence of the Scribes - which may set us on a path leading to an accurate understanding on why the massive misrepresentations in 1 Whe Not Shems: The Way of Companions are thus:

I confess that my social and political preferences are secular, egalitarian, heterarchical and exoteric. I'm therefore quite unenthusiastic about aristocratic and theocratic aspects of the ancient Egyptian heritage. What I value is the intellectual, scientific, artistic and cultural legacy. (Armah, 2006, p. 200)

Thus, we must pose the question: Is it possible that Ataa Armah has simply teleported the eurasian rhetorical ethic of égalite (imbibed at Achimota) back to classical $K m t$ 'Black Nation/Land of Blacks' as a result of his personal preferences regardless of whether they are truly reflective of the Ancestral myths of the reasons for this clever ruse of a book are best known to him, 
the reader is left to only guess possible reasons why the sources above - textual and iconographical - are not cited. Some of these reasons may include:

1. The author only knows sources, whichever those may be, that are in line with his interpretation and does not know those that contradict it.

2. The author knows the sources but has found reason to disqualify every source that goes against his interpretation.

3. The author knows the sources but finds all sources that contradict his interpretation to be irrelevant.

4. Related to \#3, the author has made a decision, for whatever reason, that Plato (Armah, 2018, pp. 102-3, 134, 219222) at 894 words quoted and Hitler (Armah, 2018, pp. 116-119), at 182 words quoted, both mentioned over 50 times each, are the sources he will cite at length in the book ostensibly about a concept from $\square m t$ 'Black Nation/Land of Blacks,' while the only quote from $\square$ Kmt 'Black Nation/Land of Blacks' herself-whose

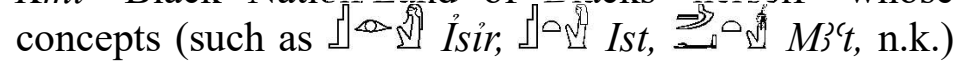
he purports to represent-will amount to a whopping six (6) words in total.

5. The author knows the sources that contradict his interpretation but has made a conscientious decision not to cite any source on his view of so-called pre-dynastic as egalitarian=good and so-called dynastic as hierarchical=bad.

Indeed, Ataa Armah's teleportation of the eurasian rhetorical ethic of 'egalitarianism' into antiquity is severely lacking in evidence in the form of primary, secondary, tertiary, iconographical or archaeological sources from the well over 3,000-year-long ancient record of the people' for whom he purports to speak. Further, the two 
sources to which he even obliquely refers are at odds with his interpretation.

It appears that not all victims of eurasian cultural and political imperialism are able to see through the veil of dishonesty encapsulated in the eurasian rhetorical ethic. In fact, feelings of inadequacy due to one's own people lacking a written constitution with high-sounding ideals and flowery language may lead to an alienated Afrikan taking the eurasian rhetoric, painting it Black, and back-dating it via a conveniently clever, yet tenuous, ruse.

Dint $K m$ t $(y w)$ 'Black people' so victimized by early exposure to the rhetorical ethic and lacking a cultural immune system to recognize it for what it is may not realize that the rhetorical ethic of saying flowery things while acting in the opposite manner is not to be admired or emulated, nor is it

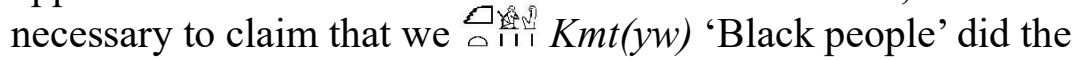
same thing in mythic times before the invention of writing. The rhetorical ethic is fraud and hypocrisy as a way of life. One's people not having such a tradition of enshrined hypocrisy is actually a good thing. Indeed, once disarmed by the flowery language, a victim of the eurasian rhetorical ethic may internalize it and even attempt to drape eurasian hypocrisy in kente cloth. But why should such a victim appropriate it as part and parcel of the character of ! and all sources of myths about ป⿻ this assertion? Why should one back-date the rhetorical ethic to the era of myths and before writing existed - that is to say socalled "predynastic" times? Perhaps in hopes that the discussion would be couched in mythical interpretations (your opinion vs. my opinion) rather than the evidence and facts of what these myths actually say. In his foray into the apparent safety of predynastic times as a viable canvas to create his pastime paradise, Ataa Armah seems to have forgotten that just because there was no writing at that time, it does not mean that there is no evidence (further iconographical and archaeological evidence will be 
presented in the follow-up to this article). Indeed, it should be noted that between ignorance of sources and intentional fraud, of the two the former is by far the more desirable. This begs the question of is this not the same fraud that one has excoriated eurasians for having perpetrated? How can fraud perpetrated by our enslavers and colonizers be uprooted by more fraud; only this time perpetrated by ourselves against our Ancestors? Is this not yet another piece of evidence of the eurasian rhetorical ethic, enshrined in the statue of égalité, having been internalized via eurasian thought, word, and deed within the alienated Afrikan? Having thus been enticed and infected by the eurasian rhetorical ethic, the victim thereof then becomes a host; a propagator of it much like how the cordyceps fungus infects an ant and thereby subsequently wipes out its entire ant colony. However, the truth of the content of those myths about the 797 Ntrw 'divinties' of so-called pre-dynastic times are readily accessible today since they were written in whole and/or in part by the 'Black People' themselves. Those who know how to read it $m d w n \underline{t r}$ 'hieroglyphs' for themselves as well as those who can access translations as presented above, thus, do not have to rely on fiction masquerading as non-fiction nor must we settle for the statue of égalité masquerading as $\triangleq M^{3} t$ 'Maat'. 


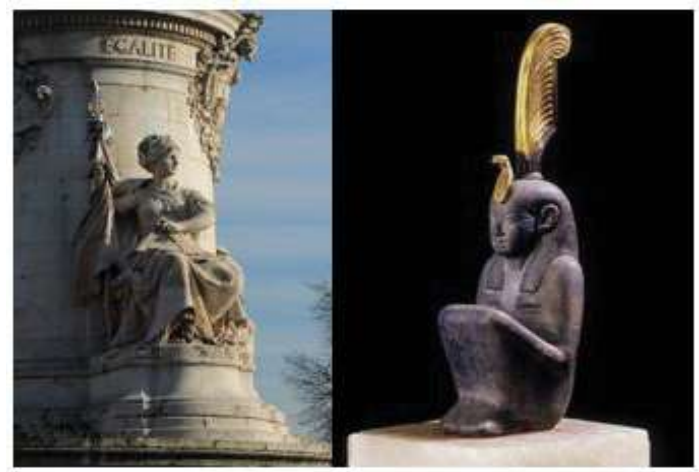

Figure 2: Left: the eurasian rhetorical ethic of égalité (hypocrisy, falsehood, and fraud) masquerading as Right: Maat (truth)

It is also at this juncture that we return to the irony of Ataa Armah's lament about those who "have spent their careers lying to African children about African history, philosophy, science, literature, and culture" (Armah, 2018, p.12). The reader is again left to wonder whether it is proper to expect a career novelist - a writer of fiction - to one day decide to weigh himself down with the encumbrances of historical accuracy, evidence, documentation, and truth when it is so much easier to write "theends-justify-the-means" fiction in the style of the victorious "Seth" of his own imagination. In his articulated view, he attributes $\mathrm{n}$. $\mathrm{n}$ th 'Seth's' supposed success as being due to the use of clever ruse. Therefore, to counter it, has he not brought forth his book as a counter-ruse in service of the eurasian deity égalité? As such, has not his perhaps genuine misapprehension of the facts of what the myths actually say led to a perverted solution in which the $\mathrm{N}$ sth 'Seth' of his imagination-born of Plutarch's paraphrases - has bequeathed him a method of deceit as the sure-fire way to victory and success?

In Wat Nhemsw: The Way of Companions, Ataa Armah is effectively creating his own myth and history without telling us he is doing so. His reference to 
classical $\square$ Kmt 'Black Nation/Land of Blacks' as well as his utilization of the names of mythic and historical figures appear to constitute a veneer that covers his design of disguising the statue of égalité as some of these same names in the aforementioned work of fiction he wrote called Osiris Rising. The difference is that that book was declared as a fiction. Whe Way of Companions is not overtly presented as fiction; thus the unsuspecting reader ( $\varepsilon . n .{ }^{16}$ victim) is left thinking that a career fiction writer has now dedicated himself to historical accuracy.

It may appear ironic to the critical reader that, paradoxically, Ataa Armah is discussing $\Rightarrow$ without giving the reader the benefit of learning the truth of what the myth and history in question actually say. In Wat Nt Shemsw: The Way of Companions we find a case of modern-day imagining disguised as ancient remembering. We should keep in mind, however, that what is being imaginedpeople saying everyone is equal-is not a new thing, but is rather part and parcel of the eurasian rhetorical ethic reborn. Curiously, in another publication of Ataa Armah and his $\check{s} m s w$ 'followers' it states, that "Maat needs no legitimizing lie. Maat is about truth, justice, balance, reciprocity, not as abstract principles, but as practical living guidelines..." (Bak, 2016, p. $\mathrm{x})$. If $M{ }^{\prime} t$ 'Maat' indeed needs no legitimizing lie, then $\Rightarrow$ M't 'Maat' does not need for The Way of Companions - the bait-and-switch whereby we come for $\Rightarrow 0$ if $M^{\prime}$ ' $t$ 'Maat' but instead end up with generous helpings of the rhetorical ethic of égalité. The statue of égalité should not be dressed up in $\Rightarrow_{0} M^{3} t$ 'Maat's' clothes.

In conclusion, not only is $\Rightarrow 0$ 通 $M^{3}$ 't 'Maat' not "egalitarianism," she is also not:

16 eno ne-Akan for "that is to say" 
Table 1: What $\triangleq \circ$ N $^{3}$ 't 'Maat' is Not - an abridged list

\begin{tabular}{|l|l|}
\hline Democracy & Rationalism \\
\hline Individualism & Christianity \\
\hline Capitalism & Socialism \\
\hline Communism & Enlightenment \\
\hline human rights & Scientism \\
\hline Liberalism & conservativism \\
\hline non-violence & Feminism \\
\hline Secularism & Royalty \\
\hline Hierarchy & Heterarchy \\
\hline Anarchy & Exotericism \\
\hline Intellectualism & Emotionalism \\
\hline rhetorical ethicism & Achimotanism \\
\hline
\end{tabular}

or any other conceptual manifestation of the eurasian rhetorical ethic in Blackface, wearing an Afrikan mask and palmed off as authentic.

Finally, it is clear that Ataa Armah and his Pris šmsw 'followers' are abundantly aware that $\Rightarrow 0 M^{3}$ ' $t$ 'Maat' is not egalitarianism as in their own book $p n$ 'Story of this Peasant Farmer' with their own carte blanche to translate as they saw fit, the word $\triangleq \circ M^{3} t$ ' Maat' appears no less than 25 times. However, forgetful of the clever ruse of égalité wearing her $\triangleq 0$ f $M^{3}$ 't 'Maat' mask, they found not even one single instance in which they could translate $\Rightarrow$ $M^{\prime \prime} t$ 'Maat' as "egalitarianism" as shown in Table 2. 
Table 2: Ataa Ayi Kwei Armah and his Shemsw Bak group's

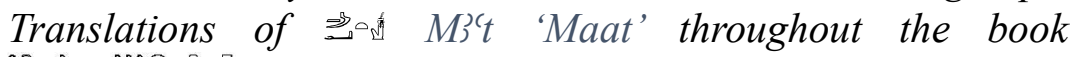
1

\begin{tabular}{|c|c|c|c|c|c|c|}
\hline Right & Truth & \begin{tabular}{|l} 
Justice/Justly \\
\end{tabular} & $\begin{array}{l}\text { Good } \\
\text { cause }\end{array}$ & $\begin{array}{l}\text { Maat } \\
\text { (untranslated) }\end{array}$ & Honestly & Egalitarianism \\
\hline $\begin{array}{l}4 \text { times } \\
\text { (pp.102, } \\
209,224, \\
404)\end{array}$ & $\begin{array}{l}7 \text { times } \\
\text { (pp.100, } \\
255,323,404 \\
\text { (truly),435, } \\
436,454)\end{array}$ & $\begin{array}{l}11 \text { times } \\
\text { (pp.87, } \\
139,225, \\
226,287,331, \\
359,408,422 \\
(\text { justly x 3)) }\end{array}$ & $\begin{array}{l}1 \text { time } \\
\text { (p. 280) }\end{array}$ & $\begin{array}{l}1 \text { time } \\
\text { (p. 404) }\end{array}$ & $\begin{array}{l}1 \text { time } \\
\text { (p. 330) }\end{array}$ & $\begin{array}{l}0 \text { times } \\
(\text { p. ø) }\end{array}$ \\
\hline
\end{tabular}

Similarly, $\vec{b} \vec{\gamma}-\mathrm{m}^{\text {‘c }}$ 'true/just', the masculine modifier (which agrees for gender and number) appears 8 times throughout their work, however, again, Ataa Ayi Kwei Armah and his $\check{s} m s w$ 'followers' were not able to find one single occasion in

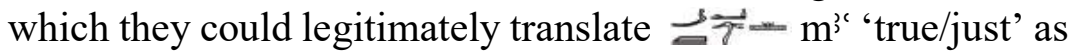
"egalitarianism" either as evident in Table 3.

Table 3: $m^{\varsigma}$ attested in Shemsw Bak's Skhty Pn

\begin{tabular}{|c|c|c|c|c|}
\hline Just/Justified & Truly & Attention & Decent & Egalitarianism \\
\hline (pp. 106 (justified) & (pp. 108, 386) & (p. 64) & (p. 139) & 0 times \\
\hline $\begin{array}{l}352, \quad 452, \quad 476 \\
\text { (justified)) }\end{array}$ & & & & (p. ø) \\
\hline
\end{tabular}

Perhaps they forgot that the new-fangled $\Rightarrow 0$ 角 $M^{3} t$ 'Maat' is supposed to conform to so-called "Enlightenment" values and mean "egalitarianism" and not what $\Rightarrow$ 'Maat' actually means as attested from the texts of $\mathrm{Kmt}$ 'Black Nation/Land of Blacks.'

Ultimately, $\Rightarrow$ 通 $M^{3}$ 't 'Maat' is utterly bound and gagged, disfigured, and violated due to the intentional or unintentional falsehoods and misrepresentations of the myths and history of classical $K m t$ 'Black Nation/Land of 
Blacks' advanced in of Companions. Our efforts at accurately presenting the facts of what the sources of information about the myths actually say in this review may thus be considered as in alignment with our endeavor to restore $\triangleq \circ M^{\prime}$ 't 'Maat' as truth instead of Ataa Armah's fraudulent "égalite" dressed up as $\cong 0$ 通 $M^{3} t$ 'Maat'. Our restoration herein constitutes defending the sanctity of our shared Ancestral heritage of classical $\square \approx m t$ 'Black Nation/ Land of Blacks' and cautioning against the miseducation that Wat Nt Shemsw: The Way of Companions may engender.

In this paper, we have shown how Ataa Armah's reimagined "Osiris" is at odds with the texts of $\mathrm{Kmt}$ 'Black Nation/Land of Blacks'-the ultimate source of any and all

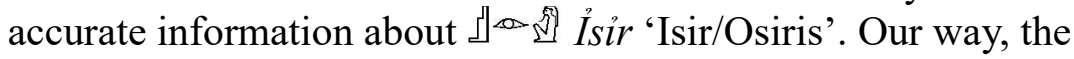
way, cannot be the way of falsehood in worship of the statue of égalité. Our way must be the way of $\triangleq 0$ if $M^{\prime}$ 't 'Maat' in presenting the truth of our past so that we may truly drink fresh water from the deep well of our ancient worldview. 


\section{References}

Ani, M. (1994). Yurugu: An African Centred Critique of European Cultural Thought and Behavior. Trenton, NJ: Africa World Books.

Appiah, P., Appiah, K. A., \& Agyeman-Duah, I. (2001). Bu Me Be: Akan Proverbs. Accra: Centre for Intellectual Renewal.

Armah, A. K. (1995). Osiris Rising: A Novel of Africa Past, Present and Future. Popenguine, Senegal: Per Ankh.

Armah, A. K. (2002). KMT: In the house of life: An epistemic novel. Popenguine, Senegal: Per Ankh.

Armah, A. K. (2006). The Eloquence of the Scribes. Popenguine, Senegal: Per Ankh.

Armah, A. K. (2013). The Resolutionaries: A Novel. Popenguine, Senegal: Per Ankh.

Armah, A. K. (2018). Wat nt Shemsw: The Way of Companions. Popenguine, Senegal: Per Ankh.

Bak, S. (2016). Smi n Skhty Pn: Multilingual translation of a 4,000-yearold-African story. Popenguine, Senegal: Per Ankh.

Carruthers, J. H. (1995). Mdw Ntr. London: Karnak House.

Fanon, F. (1963). The Wretched of the Earth. New York: Grove.

Gardiner, A. H. (1981). Late-Egyptian Stories (Vol. 1): Édition de la Fondation Égyptologique Reine Élisabeth.

Graham, K. (2016, 21 January 2019). Evidence of earliest massacre found dates back 10,000 years. Retrieved from http://www.digitaljournal. com/science/evidence-of-earliest-massacre-found-dates-back-10000-years/article/455457\#ixzz67UOA6uJY

Hamblin, W. J. (2006). Warfare in the ancient Near East to 1600 BC: Holy warriors at the dawn of history. London \& New York: Routledge.

Hendrickx, S., Darnell, J. C., \& Gatto, M. C. (2012). The earliest representations of royal power in Egypt: the rock drawings of Nag el-Hamdulab (Aswan). Antiquity, 86(334), 1068-1083.

Lahr, M. M., Rivera, F., Power, R. K., Mounier, A., Copsey, B., Crivellaro, F., . . . Foley, R. A. (2016). Inter-group violence among early Holocene hunter-gatherers of West Turkana, Kenya. Nature, 529(7586), 394-398. doi:10.1038/nature 16477

Lichtheim, M. (1976). Ancient Egyptian Literature: A Book of Readings: The New Kingdom (Vol. 2). Oakland: University of California. Lichtheim, M. (2006). Ancient Egyptian Literature: Volume III: The Late Period (Vol. 3). Oakland: Univ of California Press.

Moret, A. (1930) La légende d'Osiris à l'époque thébaine d'après l'hymne à Osiris du Louvre, dans : Bulletin de l'Institut Français d'Archéologie Orientale 30, Le Caire 1930, pp. 725-750. Museum, B. (Cartographer). (2019). Map of cemetery 117 at Jebel Sahaba [ ]. Retrieved from https://blog.britishmuseum.org/violence-andclimate-change-in-prehistoric-egypt-and-sudan/ 
Payne, J. C. (1993). Catalogue of the Predynastic Egyptian Collection in the Ashmolean Museum: Oxford University Press, USA.

Petrie, W. M. F. (1896). Naqada and Ballas: 1895. London: B. Quaritch.

Petrie, W. M. F. (1901). The royal tombs of the first dynasty. Cambridge: Cambridge University Press.

Plutarch. (1936). Isis and Osiris (F. C. Babbitt, Trans. Vol. V). Cambridge: Harvard University Press.

Quibell, J., \& Green, F. (1902). Hierakonpolis, vol. II. London: Bernard Quaritch.

Roy, J. (2011). The politics of trade: Egypt and Lower Nubia in the 4th millennium $B C$. Leiden, Boston: Brill.

Stetka, B. (2016). Prehistoric Carnage Site Is Evidence of Earliest Warfare: Discovery of 27 skeletons in Kenya point to the primal origins of conflict. Retrieved from https://www.scientificamerican.com/ article/prehistoric-carnage-site-is-evidence-of-earliest-warfare/

Von Beckerath, J. (1999). Handbuch der ägyptischen Königsnamen. Darmstadt, Germany: Philip von Zabern.

Vygus, M. (2015). Middle Egyptian Dictionary.

Williams, B. (1986). OINE 3. Excavations Between Abu Simbel and the Sudan Frontier, Part 1: The A-Group Royal Cemetery at Qustul, Cemetery L. Chicago: The Oriental Institute.

Woodson, C. G. (1933 (2005)). The Mis-education of the Negro. Drewryville, VA: Khalifah's Booksellers \& Associates. 